\title{
Combining Ability of Pod Yield and Related Traits of Groundnut (Arachis hypogaea L.) under Salinity Stress
}

\author{
Md. Abul Kalam Azad, ${ }^{1}$ Md. Shah-E-Alam, ${ }^{2}$ Md. Abdul Hamid, \\ Mohd Y. Rafii, ${ }^{4}$ and M. A. Malek ${ }^{1,4}$ \\ ${ }^{1}$ Plant Breeding Division, Bangladesh Institute of Nuclear Agriculture, Mymensingh 2202, Bangladesh \\ ${ }^{2}$ Department of Genetics and Plant Breeding, Bangladesh Agricultural University, Mymensingh 2202, Bangladesh \\ ${ }^{3}$ FormerDirector General, Bangladesh Institute of Nuclear Agriculture, BAU Campus, Mymensingh 2202, Bangladesh \\ ${ }^{4}$ Institute of Tropical Agriculture, Universiti Putra Malaysia (UPM), 43400 Serdang, Selangor, Malaysia
}

Correspondence should be addressed to Mohd Y. Rafii; mrafii@upm.edu.my and M. A. Malek; malekbina@gmail.com

Received 22 August 2013; Accepted 1 October 2013; Published 9 March 2014

Academic Editors: X. Nie and G. Pellegrino

\begin{abstract}
Copyright (C) 2014 Md. Abul Kalam Azad et al. This is an open access article distributed under the Creative Commons Attribution License, which permits unrestricted use, distribution, and reproduction in any medium, provided the original work is properly cited.

A study was performed using $6 \times 6 \mathrm{~F}_{1}$ diallel population without reciprocals to assess the mode of inheritance of pod yield and related traits in groundnut with imposed salinity stress. Heterosis was found for pod number and yield. Data on general and specific combining ability (gca and sca) indicated additive and nonadditive gene actions. The gca: sca ratios were much less than unity suggesting predominant role of nonadditive gene effects. Cultivars "Binachinabadam-2" and "Dacca-1" and mutant $\mathrm{M}_{6} / 25 / 64-82$ had the highest, second highest, and third highest pod number, as well as gca values, respectively. These two cultivars and another mutant $\mathrm{M}_{6} / 15 / 70-19$ also had the highest, second highest, and third highest pod yield, as well as gca values, respectively. Therefore, "Dacca-1", "Binachinabadam-2", $\mathrm{M}_{6} / 25 / 64-82$, and $\mathrm{M}_{6} / 15 / 70-19$ could be used as source of salinity tolerance. Cross combinations showing high sca effects arising from parents with high and low gca values for any trait indicate the influence of nonadditive genes on their expression. Parents of these crosses can be used for biparental mating or reciprocal recurrent selection for developing high yielding varieties. Crosses with high sca effects having both parents with good gca effects could be exploited by pedigree breeding to get transgressive segregants.
\end{abstract}

\section{Introduction}

Salinity is one of the most serious environmental factors limiting crop productivity worldwide [1]. This stress is complex and causes a number of detrimental effects: (i) reduces the ability of plants to absorb water, called water, or osmotic stress, (ii) causes ionic imbalance, (iii) imposes hyperosmotic shock by decreasing chemical activity of water and causing loss of cell turgor, and (iv) reduces chloroplast stromal volume and generates reactive oxygen species (ROS). Globally, nearly 100 million ha of land is affected by salinity which accounts for $6-7 \%$ of the total arable land [2]. In Bangladesh, in the coastal belt, 1.02 million ha of cultivated land is affected by varying degrees of soil salinity, 2.0 to $>16 \mathrm{dS} / \mathrm{m}[3,4]$. Soil salinity in these areas remains lower from June to November but increases and accentuates from May onwards [5].
Cultivation of high water demanding crop is not possible during the dry period (November to May) in the saline areas of Bangladesh because lack of suitable irrigation water. Groundnut (Arachis hypogaea L.) requires only $350 \mathrm{~mm}$ water to complete its life cycle [6] and is mostly grown under rainfed conditions during November to April/May. The climatic and edaphic conditions of saline areas of Bangladesh are suitable for growing groundnut, but this is limited by soil salinity and high $\mathrm{pH}[4,7]$. In order to grow in these conditions, a groundnut cultivar needs to tolerate up to $8 \mathrm{dS} / \mathrm{m}$ salinity. If this was possible the groundnut area could be expanded to an additional 0.596 million hectares of saline-affected soil.

In order to design an appropriate selection strategy for the trait(s) of interest, it is imperative to assess the mode of its inheritance, especially with respect to being additive or nonadditive. Diallel analysis $[8,9]$ helps to identify parents 
with additive and nonadditive effects for specific traits that may be used in breeding [10]. Prediction of genetic diversity and general combining ability (gca) of parents before crossing reduces the number of crosses and progenies to be screened which reduces cost and time [11]. No data are available for groundnut till under salinity stress condition, and therefore, this study was set up to (i) elucidate the mode of inheritance of genes governing the expression of pod yield and related traits under $8 \mathrm{dS} / \mathrm{m}$ salinity stress, (ii) select parents for hybridization programs in developing salt tolerant groundnut cultivars, and (iii) assess good specific combining parental lines.

\section{Materials and Methods}

2.1. Materials. A $6 \times 6 \mathrm{~F}_{1}$ diallel population without reciprocal was used in this study. The parents of this population were discriminated as being salt tolerant/sensitive based on pod number and yield under salt stress [12]. Four salt tolerant mutants/cultivars: $M_{6} / 15 / 70-19$, "Binachinabadam1 ", $\mathrm{M}_{6} / 25 / 64-82$, and "Binachinabadam-2" and 2 sensitive cultivars: "Dacca-1" and "Zhingabadam" were crossed following the method of Kumar and Patel [13] with some modifications. The source, origin, method of development, and botanical type of the parents are shown in Table 1. It is important to mention here that the parent of "Binachinabadam1", "Binachinabadam-2", $\mathrm{M}_{6} / 15 / 70-19$, and $\mathrm{M}_{6} / 25 / 64-82$ was Mut-6. Mutant-6 was derived by irradiating the seeds of "Dacca-1", a local land race; thus, "Dacca-1" is the common parent of "Binachinabadam-1", "Binachinabadam-2", $\mathrm{M}_{6} / 15 / 70-19$, and $\mathrm{M}_{6} / 25 / 64-82$.

2.2. Experimental Site, Experiment Design, and Plant Culture. The experiment was conducted in the glasshouse of Bangladesh Institute of Nuclear Agriculture (BINA), Mymensingh, with temperature and relative humidity ranges of $25-35^{\circ} \mathrm{C}$ and $70-90 \%$, respectively. The study was set up as a completely randomized design with four replications, under $8 \mathrm{dS} / \mathrm{m}$ salinity level, imposed during flowering till harvest stages as flowering stage is the most sensitive stage to salinity stress [14]. Five pregerminated seeds of each parent and cross were sown on February 11, 2007 in earthen pots of size $27 \times 22 \mathrm{~cm}$, lined with polyethylene sheet and filled with $8.0 \mathrm{~kg}$ soil mixture, prepared with sandy loam soil and well-rotted farm yard manure in a 1:1 ratio. The fertilizer needed for each pot was determined following the Fertilizer Recommendation Guide-2005 [15]. The total amount of nitrogen, phosphorus, potassium, sulphur, and zinc was applied in the form of urea, triple super phosphate (TSP), muriate of potash (MP), gypsum, and zinc sulphate. These were mixed thoroughly with the soil in each pot before sowing. When the plants were established, only three healthy plants were kept in each pot. The pots were kept free from weeds and protected from insect pests and diseases by spraying appropriate pesticides as and when necessary.

2.3. Imposing Salinity and Data Recording. Saline water was synthesized by using a mixture of different salts: $50 \% \mathrm{NaCl}$, $15 \% \mathrm{Na}_{2} \mathrm{SO}_{4}, 10 \% \mathrm{NaHCO}_{3}, \mathrm{CaCl}_{2}$, and $\mathrm{MgCl}_{2}$ together with
$5 \% \mathrm{MgSO}_{4}$ by weight to simulate saline ground water of saline areas of Bangladesh [4]. A stock solution was prepared by dissolving 50 grams of the salt mixture in 1 liter of tap water. The salinity of the stock solution was then adjusted to $80 \mathrm{dS} / \mathrm{m}$. The total amount of stock solution needed to raise $8 \mathrm{dS} / \mathrm{m}$ salinity of the soil mixture was estimated with the following equation:

$$
V_{1} S_{1}=V_{2} S_{2}
$$

where

$$
\begin{aligned}
& V_{1}=\text { volume of soil mixture in a pot, } \\
& S_{1}=\text { desired salinity - initial salinity of the soil, } \\
& V_{2}=\text { volume of water at } 70-80 \% \text { plant available water } \\
& \text { (PAW), } \\
& S_{2}=\text { salinity of stock solution. }
\end{aligned}
$$

Volume of soil mixture $\left(V_{1}\right)$ was determined using the following formula:

$$
V_{1}=\frac{\text { Weight of oven dried soil }}{\text { Bulk density of soil }} .
$$

Volume of water $\left(V_{2}\right)$ was determined by dividing the weight of water by its density $(0.98 \mathrm{~g} / \mathrm{cc})$.

The estimated amount of stock solution was then diluted to the desired salinity levels by adding tap water and then applied from flowering until harvest. The total amount of saline water for the respective treatments was applied in installments. At each installment, 0.5 to 1.0 liter saline water was applied so that the moisture content of the pots remained between 70 and $80 \%$ of PAW. For the control, the same amount of tap water was applied. All plants in a pot were uprooted at full maturity and washed with running tap water. Plant height, branch number, and pod number were recorded before sun drying. After sun drying, pod yield per plant was recorded. There were altogether 12 plants in each $\mathrm{F}_{1}$ populations, three plants in a pot and 4 such pots in each population.

2.4. Genetic Analysis. Combining ability analysis was performed following Method 2, Model 1 of Griffing [16]. ANOVA for combining ability analysis in Method 2 Model 1 is shown in Table 2.

2.5. Model Followed. The mathematical model for the combining ability analysis in model 1 was as follows:

$$
Y_{i j}=m+g_{i}+g_{j}+s_{i j}+\frac{1}{b c} \sum \sum e_{i j k l},
$$

where $i, j=1, \ldots, n$ ( $n=$ number of parents), $k=1, \ldots, b(b=$ number of blocks/replications), and $l=1, \ldots, c(c=$ number of observation in each plot).

$Y_{i j}$ is the mean of $i \times j$ th genotype over $k$ and $l ; m$ is the population mean; $g_{i}$ is the gca effect of $i$ th parent; $g_{j}$ is the gca effect of $j$ th parent. $s_{i j}$ is the sca effect and $1 / b c \sum \sum e_{i j k l}$ is the mean error effect. 
TABLE 1: Origin/sources of the groundnut genotypes used in this experiment together with method of development.

\begin{tabular}{|c|c|c|c|c|c|c|}
\hline SL. no. & Genotype & $\begin{array}{l}\text { Botanical } \\
\text { type }\end{array}$ & Origin & $\begin{array}{l}\text { Status and method of } \\
\text { development }\end{array}$ & Parent & $\begin{array}{c}\text { Gamma-ray } \\
\text { dose (KR) }\end{array}$ \\
\hline 1 & "Dacca-1" & Spanish & BARI & Introduction & - & - \\
\hline 2 & "Zhingabadam" & Valencia & BARI & Introduction & - & - \\
\hline 3 & $\mathrm{M}_{6} / 15 / 70-19$ & Spanish & BINA & $\begin{array}{l}\text { Mutant selected after } \\
\text { mutation induction }\end{array}$ & Mut-6 & 15 \\
\hline 4 & "Binachinabadam-1" & Spanish & BINA & $\begin{array}{l}\text { Variety } \\
\text { developed after mutation }\end{array}$ & Mut-6 & 20 \\
\hline 5 & $\mathrm{M}_{6} / 25 / 64-82$ & Spanish & BINA & $\begin{array}{l}\text { Line selected after mutation } \\
\text { induction }\end{array}$ & "Dacca-1" & 35 \\
\hline 6 & "Binachinabadam-2" & Spanish & BINA & $\begin{array}{l}\text { Variety } \\
\text { developed after mutation } \\
\text { induction }\end{array}$ & Mut-6 & 25 \\
\hline
\end{tabular}

BARI: Bangladesh Agricultural Research Institute.

TABLE 2

\begin{tabular}{lcccc}
\hline Source & $\mathrm{df}$ & $\mathrm{SS}$ & $\mathrm{MS}$ & Expected mean squares \\
\hline gca & $p-1$ & $\mathrm{SSg}$ & $\mathrm{Mg}$ & $\delta^{2} e+((p+2) /(p-1)) \sum g^{2} i$ \\
sca & $p(p-1) / 2$ & $\mathrm{SSs}$ & $\mathrm{Ms}$ & $\delta^{2} e+(2 / p(p-1)) \sum \sum s^{2} i j$ \\
Error & $(b-1)(e-1)$ & $\mathrm{SSe}$ & Mé & $\delta^{2} e$ \\
\hline
\end{tabular}

Note: $p$ stands for number of parents.

Restrictions imposed are $\sum_{i} g_{i}=0$ and $\sum_{j} s_{i j}+s_{i i}=0$ (for each $i$ ).

The sum of squares (SS) were calculated as follows:

$$
\begin{gathered}
\mathrm{SS}_{g}=\frac{1}{n+2}\left[\sum_{i}\left(Y_{i} \cdot+Y_{i i}\right)^{2}-\frac{4}{n} Y^{2} . .\right], \\
\mathrm{SS}_{s}=\sum \sum Y_{i j}^{2}-\frac{1}{n+2} \sum\left(Y_{i}+Y_{i i}\right)^{2} \\
+\frac{2}{(n+1)(n+2)} Y^{2} . .
\end{gathered}
$$

where $\mathrm{SS}_{g}$ is the sum of squares due to gca, $\mathrm{SS}_{s}$ is the sum of squares due to sca, $Y_{i}$ is the array total of the $i$ th parent, $Y_{i i}$ is the mean value of the $i$ th parent, $Y$.. is the grand total of the $1 /(2 \mathrm{n}(\mathrm{n}-1))$ crosses and parental values, and $Y_{i j}$ is the progeny mean values in the diallel table.

Thus the effects were calculated as follows:

$$
\begin{gathered}
g_{i}=\frac{1}{n+2}\left[\sum\left(Y_{i}+Y_{i i}\right)-\frac{2}{n} Y_{. .}\right], \\
s_{i j}=Y_{i j}-\frac{1}{n+2}\left[Y_{i \cdot}+Y_{i i}+Y_{\cdot j}+Y_{j j}\right] \\
+\frac{2}{(n+1)(n+2)} Y_{. .}
\end{gathered}
$$

Variance of effects was calculated as follows:

(i) $\operatorname{Var}\left(g_{i}\right)=(n-1) \delta^{2}{ }_{e} / n(n+2)$,

(ii) $\operatorname{Var}\left(s_{i j}\right)=2(n-1) \delta_{e}^{2} /(n+1)(n+2)$.

SE (standard error) was calculated as the square root of the variance.

\section{Results}

3.1. ANOVA and Mean Squares. Mean squares (ANOVA) for pod yield and some related traits of a $6 \times 6 \mathrm{~F}_{1}$ half diallel population at $8 \mathrm{dS} / \mathrm{m}$ salinity stress are presented in Table 3 . Results revealed highly significant $(P \leq 0.01)$ differences between genotypes for plant height, branch number, pod number, and pod yield and not significant difference for branch number. The parents showed such significant differences for plant height and pod yield but just significant and not significant differences for pod and branch number. Like genotype, the $\mathrm{F}_{1} \mathrm{~s}$ showed highly significant differences for all the traits, but the term $P$ versus $F_{1}$ appeared highly significant for pod number and yield but not significant for all the other traits.

3.2. Means. Means of pod yield and some related traits of the parents at $8 \mathrm{dS} / \mathrm{m}$ salinity stress, imposed during flowering till harvesting stages, are presented in Table 4 . In this experiment, "Zhingabadam" had the tallest height, appeared statistically identical with "Dacca-1" only. However, the mutant $\mathrm{M}_{6} / 15 / 70-19$ had the shortest height showing significant difference with all others except "Binachinabadam-2". Branch number did not show any significant difference amongst the parents. Pod number was the highest in "Binachinabadam2 ", and it differed significantly with that of all the remainders. In this experiment, only "Zhingabadam" failed to produce any pod. However, 3 of the 6 mutants/varieties did not have any mature pod, and thus they have no pod yield. Of the remaining three, "Binachinabadam-2" had significantly the highest pod yield followed by "Dacca-1". 
TABLE 3: Analysis of variance of pod yield and related traits in a $6 \times 6 \mathrm{~F}_{1}$ diallel population at $8 \mathrm{dS} / \mathrm{m}$ salinity imposed during flowering till harvest stages.

\begin{tabular}{|c|c|c|c|c|c|}
\hline Sources of variation & $\mathrm{df}$ & Plant height & Branch number & ${ }^{++}$Pod number & ${ }^{++}$Pod yield \\
\hline Genotype & 20 & $55.88^{* *}$ & $0.63^{* *}$ & $0.85^{* *}$ & $0.45^{* *}$ \\
\hline Parent $(\mathrm{P})$ & 5 & $109.13^{* *}$ & 0.06 & $1.41^{*}$ & $0.71^{* *}$ \\
\hline $\mathrm{F}_{1} s$ & 14 & $40.81^{* *}$ & $0.83^{* *}$ & $0.61^{* *}$ & $0.35^{* *}$ \\
\hline$P$ versus $F_{1}$ & 1 & 0.70 & 0.63 & $1.34^{* *}$ & $0.67^{* *}$ \\
\hline Error & 42 & 3.42 & 0.20 & 0.01 & 0.01 \\
\hline
\end{tabular}

* * indicates significant at $P \leq 0.05 ;++$ indicates square-root transformed data used.

TABLE 4: Means of pod yield and related traits of the parents as influenced by $8 \mathrm{dS} / \mathrm{m}$ salinity imposed during flowering till harvest stages.

\begin{tabular}{lcccc}
\hline Parents & Plant height $(\mathrm{cm})$ & Branch/plant (no.) & ${ }^{++}$Pod/plant (no.) & ${ }^{++}$Pod yield/plant $(\mathrm{g})$ \\
\hline "Dacca-1" & 23.83 & 3.89 & 2.33 & 1.53 \\
"Zhingabadam" & 24.50 & 3.84 & 0.71 & 0.71 \\
$\mathrm{M}_{6} / 15 / 70-19$ & 10.17 & 4.00 & 1.41 & 1.06 \\
"Binachinabadam-1" & 17.25 & 4.17 & 1.79 & 0.71 \\
$\mathrm{M}_{6} / 25 / 64-82$ & 13.33 & 4.00 & 2.26 & 0.71 \\
"Binachinabadam-2" & 12.67 & 3.78 & 2.51 & 1.86 \\
LSD & 3.01 & $\mathrm{NS}$ & 0.01 & 0.01 \\
\hline
\end{tabular}

NS: nonsignificant; ++: square-root transformed data.

TABLE 5: Analysis of variance for combining ability of pod yield and related traits in a $6 \times 6 \mathrm{~F}_{1}$ diallel population subject to salt stress.

\begin{tabular}{lcccc}
\hline Item & df & $\begin{array}{c}\text { Plant } \\
\text { height }\end{array}$ & $\begin{array}{c}{ }^{++} \text {Pod } \\
\text { number }\end{array}$ & $\begin{array}{c}{ }^{++} \text {Pod } \\
\text { yield }\end{array}$ \\
\hline gca & 5 & $26.13^{* *}$ & $0.64^{* *}$ & $0.20^{* *}$ \\
sca & 15 & $16.13^{* *}$ & $0.16^{* *}$ & $0.13^{* *}$ \\
Error & 42 & 1.14 & 0.003 & 0.003 \\
\hline \multicolumn{5}{c}{ Variance components } \\
gca & 3.12 & 0.08 & 0.02 \\
sca & 14.98 & 0.16 & 0.13 \\
gca : sca & 0.21 & 0.49 & 0.19 \\
\hline
\end{tabular}

** indicates significance at $P \leq 0.05 ;++$ indicates square-root transformed data used.

3.3. Combining Ability. Analysis of variance data for combining ability is presented in Table 5. Results exhibited highly significant differences for general combining ability (gca) and specific combining ability (sca) effects for all the traits except branch number. Branch number showed not significant difference for gca (data not shown). The sca components of variance were always higher than that of its gca counterpart.

3.4. General and Specific Combining Ability. Estimates of gca and sca effects of the tested genotypes are presented in Tables 6 and 7, respectively. The parent "Dacca-1" showed highly significant positive gca values for all the traits, while "Binachinabadam-2" showed highly significant and positive gca values for only pod number and yield. Like the tallest cultivar, "Dacca-1", "Zhingabadam" had significant positive gca for plant height. In contrast, the shortest mutant, $M_{6} / 15 / 70$ 19, had the lowest gca for plant height. The remaining
TABLE 6: Estimates of gca effects of parental lines in a $6 \times 6 \mathrm{~F}_{1}$ diallel population for pod yield and related traits during flowering till harvest stages under $8 \mathrm{dS} / \mathrm{m}$ salinity.

\begin{tabular}{lccc}
\hline Parents & $\begin{array}{c}\text { Plant } \\
\text { height }\end{array}$ & $\begin{array}{c}{ }^{++} \text {Pod } \\
\text { number }\end{array}$ & $\begin{array}{c}{ }^{++} \text {Pod } \\
\text { yield }\end{array}$ \\
\hline "Dacca-1" & $2.63^{* *}$ & $0.38^{* *}$ & $0.15^{* *}$ \\
"Zhingabadam" & $1.42^{*}$ & $-0.41^{* *}$ & $-0.06^{*}$ \\
M $_{6} / 15 / 70-19$ & $-2.50^{* *}$ & $-0.11^{* *}$ & $0.09^{* *}$ \\
"Binachinabadam-1" & -0.04 & $-0.14^{* *}$ & $-0.19^{* *}$ \\
$\mathrm{M}_{6} / 25 / 64-82$ & -0.77 & 0.05 & $-0.17^{* *}$ \\
"Binachinabadam-2" & -0.74 & $0.23^{* *}$ & $0.17^{* *}$ \\
SE & 0.34 & 0.02 & 0.02 \\
\hline
\end{tabular}

** and * indicate significance at $P \leq 0.05$ and $P \leq 0.01$, respectively; ++ indicates square-root transformed data used.

genotypes had not significant negative gca values for plant height. The two genotypes with the highest pod number and yield (Table 4) also had highly significant positive gca values (Table 6). In contrast, all other genotypes had mostly highly significant negative (low) gca values, except $\mathrm{M}_{6} / 25 / 64-82$ for pod number.

For plant height, the cross "Binachinabadam-1" $\times$ "Binachinabadam-2" appeared as the best specific combination followed by "Dacca-1" $\times \mathrm{M}_{6} / 25 / 64$ 82, "Zhingabadam" $\times \mathrm{M}_{6} / 15 / 70-19$, and "Dacca- 1 " $\times$ "Binachinabadam-2" crosses (Table 7). These originated from crossing between parents having gca values: not significant negative versus not significant negative, highly significant positive versus not significant negative, significant positive versus highly significant negative, and highly significant positive versus not significant negative, respectively. In 
TABLE 7: Estimates of sca effects in a $6 \times 6 \mathrm{~F}_{1}$ diallel population of pod yield and related traits after salt stress.

\begin{tabular}{|c|c|c|c|}
\hline Cross combinations & Plant height & ${ }^{++}$Pod number & ${ }^{++}$Pod yield \\
\hline "Dacca-1" × "Zhingabadam" & $-6.62^{* *}$ & $0.10^{*}$ & $-0.07^{*}$ \\
\hline "Dacca-1" × $\mathrm{M}_{6} / 15 / 70-19$ & $-1.58^{*}$ & $0.66^{* *}$ & $0.20^{* *}$ \\
\hline "Dacca-1" × "Binachinabadam-1" & $-4.61^{* *}$ & -0.05 & -0.01 \\
\hline "Dacca-1" $\times \mathrm{M}_{6} / 25 / 64-82$ & $5.34^{* *}$ & $-0.24^{* *}$ & $-0.17^{* *}$ \\
\hline "Dacca-1" × "Binachinabadam-2" & $3.91^{* *}$ & $0.52^{* *}$ & $0.12^{* *}$ \\
\hline "Zhingabadam" $\times \mathrm{M}_{6} / 15 / 70-19$ & $3.96^{* *}$ & $0.19^{* *}$ & $0.18^{* *}$ \\
\hline "Zhingabadam" × "Binachinabadam-1" & $-2.67^{* *}$ & $0.30^{* *}$ & $0.28^{* *}$ \\
\hline "Zhingabadam" $\times \mathrm{M}_{6} / 25 / 64-82$ & -0.19 & $0.25^{* *}$ & $0.51^{* *}$ \\
\hline "Zhingabadam" $\times$ "Binachinabadam-2" & $-4.22^{* *}$ & $0.24^{* *}$ & -0.04 \\
\hline $\mathrm{M}_{6} / 15 / 70-19 \times$ "Binachinabadam-1" & 0.03 & $0.49^{* *}$ & $0.75^{* *}$ \\
\hline $\mathrm{M}_{6} / 15 / 70-19 \times \mathrm{M}_{6} / 25 / 64-82$ & 0.14 & $-0.10^{*}$ & $-0.10^{* *}$ \\
\hline $\mathrm{M}_{6} / 15 / 70-19 \times$ “Binachinabadam-2" & 0.12 & $-0.28^{* *}$ & $-0.44^{* *}$ \\
\hline "Binachinabadam-1" $\times \mathrm{M}_{6} / 25 / 64-82$ & -0.65 & $-0.16^{* *}$ & $-0.25^{* *}$ \\
\hline "Binachinabadam-1" $\times$ "Binachinabadam-2" & $6.83^{* *}$ & $-0.57^{* *}$ & $-0.42^{* *}$ \\
\hline $\mathrm{M}_{6} / 25 / 64-82 \times$ "Binachinabadam-2" & $-1.37^{*}$ & $0.12^{* *}$ & $0.31^{* *}$ \\
\hline SE & 0.45 & 0.02 & 0.02 \\
\hline
\end{tabular}

$*$ and $* *$ indicate significance at $P \leq 0.05$ and $P \leq 0.01$, respectively; ++ indicates square-root transformed data used.

contrast, the cross "Dacca-1" $\times$ "Zhingabadam" had the worst sca effect followed by "Dacca-1" $\times$ "Binachinabadam-1", "Zhingabadam" $\times$ "Binachinabadam-2", "Zhingabadam" $\times$ "Binachinabadam-1", "Dacca-1" $\times \mathrm{M}_{6} / 15 / 70-19$, and $\mathrm{M}_{6} / 25 / 64-82 \times$ "Binachinabadam-2". The parents of these crosses had highly significant versus just significant positive, significant positive versus not significant negative, significant positive versus not significant negative, highly significant positive versus negative, and not significant negative versus not significant negative gca values, respectively.

For pod number, 8 cross combinations showed highly significant positive sca with "Dacca-1" $\times \mathrm{M}_{6} / 15 / 70-19$ being the best followed by "Dacca-1" $\times$ "Binachinabadam2", $\mathrm{M}_{6} / 15 / 70-19 \times$ "Binachinabadam-1", "Zhingabadam" $\times$ "Binachinabadam-1", "Zhingabadam" $\times \mathrm{M}_{6} / 25 / 64-82$, "Zhingabadam" $\times$ "Binachinabadam-2", $\mathrm{M}_{6} / 25 / 64-82 \times$ "Binachinabadam-2", and "Zhingabadam" $\times \mathrm{M}_{6} / 15 / 70$ 19 (Table 7). These crosses were obtained from crossing between parents with highly significant positive versus highly significant negative, highly significant positive versus highly significant positive, highly significant negative versus highly significant negative, highly significant negative versus highly significant negative, highly significant negative versus not significant positive, highly significant negative versus highly significant positive, not significant positive versus highly significant positive and highly significant negative versus highly significant negative gca values, respectively. In contrast, all the remaining crosses except "Dacca-1" $\times$ "Zhingabadam" showed highly to just significant negative sca with "Binachinabadam-1" $\times$ "Binachinabadam2 " being the lowest and were followed by $\mathrm{M}_{6} / 15 / 70$ $19 \times$ "Binachinabadam-2", "Dacca-1" $\times \mathrm{M}_{6} / 25 / 64-82$, "Binachinabadam-1" $\times$ "Binachinabadam-2", $\mathrm{M}_{6} / 15 / 70-19$ $\times \mathrm{M}_{6} / 25 / 64-82$, and "Dacca-1" $\times$ "Binachinabadam-1" in decreasing order. These crosses were obtained from crossing between parents with highly significant negative versus highly significant positive, highly significant negative versus highly significant positive, highly significant positive versus not significant positive, highly significant negative versus not significant positive, and highly significant positive versus highly significant negative gca values, respectively.

However, for pod yield, out of 15 cross combinations, 7 had shown heterotic performances. They were "Dacca$1 " \times \mathrm{M}_{6} / 15 / 70-19$, “Dacca-1" $\times$ "Binachinabadam-2", "Zhingabadam" $\times \mathrm{M}_{6} / 15 / 70-19, \quad$ "Zhingabadam" $\times$ "Binachinabadam-1", "Zhingabadam" $\times \mathrm{M}_{6} / 25 / 64-82$, $\mathrm{M}_{6} / 15 / 70-19 \times$ "Binachinabadam-1", and $\mathrm{M}_{6} / 25 / 64-82 \times$ "Binachinabadam-2".

\section{Discussion}

Tolerance to salinity is highly influenced by the environmental factors [17]. The variety "Dacca-1" showed higher tolerance in terms of both pod number and yield when exposed to 7-9 dS/m salinity stresses from flowering till harvest stages in glasshouse condition from August to January by showing relative pod and kernel yields higher than even the unstressed treatment [18]. In contrast, the same variety when exposed to $8 \mathrm{dS} / \mathrm{m}$ salinity stress in same glass house condition from April to August could not produce any pod [12]. This was due to high temperature during the reproductive stage. Under glass house condition, sometimes the maximum temperature exceeded $50^{\circ} \mathrm{C}$ during the experimental period. The optimum air temperature during the day in groundnut ranges from $25^{\circ} \mathrm{C}$ to $30^{\circ} \mathrm{C}$ for vegetative growth and from $24^{\circ} \mathrm{C}$ to $28^{\circ} \mathrm{C}$ for reproductive growth and development $[19,20]$. This explains well the fluctuation in tolerance of the variety "Dacca-1" in the two studies. In this study, the variety "Dacca-1" appeared tolerant as it produced the second highest pod number and yield. This was attributed to the optimum temperature during the reproductive period in the 
glass house. The variety "Binachinabadam-2" and the mutant $\mathrm{M}_{6} / 15 / 70-19$ appeared tolerant in this study as these could produce pod yield (Table 4 ) and also in the screening study [12] in which temperature during the reproductive stage exceeded $50^{\circ} \mathrm{C}$. This means that these two are most tolerant to $8 \mathrm{dS} / \mathrm{m}$ salinity stress even under high temperature during the reproductive stage. Therefore, it is clear that in this study "Dacca-1", "Binachinabadam-2" and $\mathrm{M}_{6} / 15 / 70-19$ were found to be tolerant and the remainders were found to be sensitive. This may result in screening study [12].

A detailed genetic study is a prerequisite in determining the mode of inheritance of traits which ultimately helps adopt better planning and execution in a plant breeding improvement programme. This study was to assess this with respect to pod yield and some related traits in groundnut exposed to salt stress. The term parent versus offspring appeared significant for pod number and yield only but not significant difference for plant height and branch number (Table 3). This suggests presence of heterosis for pod number and yield but its absence for plant height and branch number.

The significant general and specific combining ability data (Table 5) conform to other publications [21-24] that investigated salinity tolerance in many different crops. Baker [25] suggested that general and specific combining ability should be assessed by estimating the components of variance, expressing as $\sigma_{g}^{2} / \sigma^{2}{ }_{s}$ ratio. The closer the ratio to unity is, the greater would be the magnitude of additive genetic effects. The ratios computed in this study were much less than unity (Table 5) suggesting predominant role of nonadditive gene effects in their inheritance. This result is in agreement with that of many workers working with salinity tolerance in many different crops [26-29]. The higher values of sca than gca could be due to repulsion phase linkage and linkage disequilibrium [30]. Verma and Srivastava [31] observed high sca effects resulting from the dominance and interaction or epistatic effects that exist between the hybridizing parents. Additionally, higher sca than gca can be explained in other different ways: (i) negative associations between genes [30], (ii) previous selection that narrowed the genetic base of the lines tested [32], (iii) directional selection [33], and (iv) use of closely related parents [34]. In these studies, since the genotypes used had been selected mainly for high yield, this might have narrowed their genetic bases. Moreover, most of the genotypes tested have common origins, for example, the common parent "Dacca-1", which could be a reason for narrow genetic base.

Two cultivars, "Binachinabadam-2", and "Dacca-1" and mutant $\mathrm{M}_{6} / 25 / 64-82$ with the highest, second highest, and third highest pod number, respectively, had also highest, second highest, and third highest gca values for pod number (Table 6). For pod yield, the above two cultivars and the mutant $\mathrm{M}_{6} / 15 / 70-19$ had highest, second highest, and third highest gca values (Table 6). Obviously, these four materials: "Dacca-1", "Binachinabadam-2", $\mathrm{M}_{6} / 25 / 64-82$, and $\mathrm{M}_{6} / 15 / 70$ 19 could be used as major source of salinity tolerance. The high sca effects for pod number were obtained by crossing parents with high $\times$ low, high $\times$ high, low $\times$ low, and low $\times$ high gca values (Table 6 and Table 7 ). In contrast, high sca effects for pod yield were obtained by crossing parents with either high $\times$ low or low $\times$ high gca values. The cross combinations showing high sca effects arising from parents with high and low gca values for any trait indicate that there is influence of nonadditive genes on their expression [35]. Parent of these crosses can be used for biparental mating or reciprocal recurrent selection for developing superior varieties with high yield. Crosses with high sca effects having both parents with good gca effects could be exploited by pedigree method of breeding to get transgressive segregants.

\section{Conflict of Interests}

The authors declare that there is no conflict of interests regarding the publication of the paper.

\section{Acknowledgments}

This study was supported by a research grant from Bangladesh Agricultural Research Council (BARC), Bangladesh, through a scholarship to the senior author for higher studies leading to the Ph.D. degree. The authors also duly acknowledge Dr. Brian Peter Forster, Head of Plant Breeding and Genetics Laboratory, FAO/IAEA Agriculture and Biotechnology Laboratory, International Atomic Energy Agency (IAEA) for editing the paper.

\section{References}

[1] M. Ashraf, "Breeding for salinity tolerance in plants," Critical Reviews in Plant Sciences, vol. 13, no. 1, pp. 17-42, 1994.

[2] R. Munns and R. A. James, "Screening methods for salinity tolerance: a case study with tetraploid wheat," Plant and Soil, vol. 253, no. 1, pp. 201-218, 2003.

[3] Z. Karim and A. Iqbal, Impact of Land Degradation in Bangladesh: Changing Scenario in Agricultural Land Use, Bangladesh Agricultural Research Council, Dhaka, Bangladesh, 2001.

[4] SRDI, Soil Salinity in Bangladesh 2000, Soil Resource Development Institute, Ministry of Agriculture, Dhaka, Bangladesh, 2003.

[5] M. N. Islam, M. N. Islam, and G. Mowla, "Importance of salinity management to protect environmental degradation in the coastal ecosystem of Bangladesh," in Proceedings of the Joint International Conference on Agricultural Engineering and Technology Exhibition, pp. 663-669, Bangladesh Institution of Engineers, Dhaka, Bangladesh, 1997.

[6] D. I. Field, "Land evaluation for crop diversification," Crop Diversification Program (CDP), Department of Agricultural Extension, Dhaka, Bangladesh, 1995.

[7] L. J. Reddy and A. K. Kaul, Status and Prospects of Groundnut in Bangladesh, Bangladesh Agricultural Research Council, Dhaka, Bangladesh, 1996.

[8] B. I. Hayman, "The theory and analysis of diallel crosses," Genetics, vol. 42, pp. 421-432, 1954.

[9] A. R. Dabholkar, Elements of Biometrical Genetics, Concept Publication Camp, New Delhi, India, 1992.

[10] N. Murtaza, M. Kitaoka, and G. M. Ali, "Genetic differentiation of cotton cultivars by polyacrylamide gel electrophoresis," Journal of Central European Agriculure, vol. 6, pp. 69-76, 2005. 
[11] L. S. Kumar, "DNA markers in plant improvement: an overview," Biotechnology Advances, vol. 17, no. 2-3, pp. 143-182, 1999.

[12] M. A. K. Azad, M. S. Alam, and M. A. Hamid, "Modification of salt tolerance level in groundnut (Arachis hypogaea L.) through induced mutation," Legume Research, vol. 36, no. 3, pp. 224-233, 2013.

[13] S. S. Kumar and S. A. Patel, "Crossing technique in groundnut (Arachis hypogaea)," Indian Journal of Agricultural Science, vol. 66, no. 10, pp. 589-593, 1996.

[14] M. A. K. Azad, M. M. Haque, M. A. Hamid, F. Yasmine, and M. A. W. Golder, "Tolerance to salinity stress in peanut (Arachis hypogaea L.) through osmotic adjustment and undamaged chloroplast," Legume Research, vol. 35, no. 4, pp. 271-284, 2012.

[15] BARC, Fertilizer Recommendation Guide-2005, Bangladesh Agricultural Research Council, Dhaka, Bangladesh, 2005.

[16] B. Griffing, "A generalized treatment of the use of diallel cross in quantitative inheritance," Heredity, vol. 10, pp. 31-50, 1956.

[17] G. B. Gregorio and D. Senadhira, "Genetic analysis of salinity tolerance in rice (Oryza sativa L.)," Theoretical and Applied Genetics, vol. 86, no. 2-3, pp. 333-338, 1993.

[18] M. A. K. Azad, Genetics of salt tolerance in groundnut (Arachis hypogaea L.) [Ph.D. dissertation], Bangladesh Agricultural University, Mymensingh, Bangladesh, 2008.

[19] I. M. W. Wood, "The effects of temperature at early flowering on the growth and development of peanut," Australian Journal of Agriculture Research, vol. 19, pp. 241-251, 1968.

[20] F. R. Cox, "Effects of temperature on peanut vegetative and fruit growth," Peanut Science, vol. 6, pp. 14-17, 1979.

[21] S. Moeljopawiro and H. Ikehashi, "Inheritance of salt tolerance in rice," Euphytica, vol. 30, no. 2, pp. 291-300, 1981.

[22] M. Akbar, G. S. Khush, and D. Hille Ris Lambers, "Genetics of salt tolerance in rice," in Proceedings of the International Rice Genetics Symposium, pp. 399-409, IRRI, May 1986.

[23] S. Muralia and E. V. Divakara Sastry, "Combining ability for germination and seedling establishment characters in bread wheat (Triticum aestivum) under normal and saline environments," Indian Journal of Genetics, vol. 60, no. 1, pp. 69-70, 2001.

[24] G. M. Ali, M. Murtaza, J. C. Collins, and T. McNeilly, "Study of salt tolerance parameters in pearl millet Pennisetum americanum L.," Journal of Central European Agriculture, vol. 7, pp. 365-376, 2006.

[25] R. J. Baker, "Issues in diallel analysis," Crop Science, vol. 18, pp. 533-536, 1978.

[26] G. V. Subbarao, C. Johansen, J. V. D. K. Kumar Rao, and M. $\mathrm{K}$. Jana, "Salinity tolerance in $\mathrm{F}_{1}$ hybrids of pigeonpea and a tolerant wild relative," Crop Science, vol. 30, pp. 785-788, 1990.

[27] F. M. Azhar and T. McNeilly, "The genetic basis for salt tolerance in Sorghum bicolor (L) Moench seedlings," Plant Breeding, vol. 101, pp. 114-121, 1988.

[28] Y. Saranga, D. Zamir, A. Marani, and J. Rudich, "Breeding tomatoes for salt tolerance-field-evaluation of Lycopersicon germplasm for yield and dry-matter production," Journal of the American Society for Horticultural Science, vol. 116, pp. 10671071, 1991.

[29] M. Tal and M. C. Shannon, "Salt tolerance in the wild relatives of the cultivated tomato: responses of Lycopersicon esculentum, L. cheesmanii, L. peruvianum, Solanum pennellii and $\mathrm{F}_{1}$ hybrids to high salinity," Australian Journal of Plant Physiology, vol. 10, no. 1, pp. 109-117, 1983.
[30] M. J. Sokol and R. J. Baker, "Evaluation of the assumptions required for the genetic interpretation of diallel experiments in self pollinating crops," Canadian Journal of Plant Science, vol. 57, pp. 1185-1191, 1977.

[31] O. P. Verma and H. K. Srivastava, "Genetic component and combining ability analyses in relation to heterosis for yield and associated traits using three diverse rice-growing ecosystems," Field Crops Research, vol. 88, no. 2-3, pp. 91-102, 2004.

[32] R. L. Plaisted, L. Sanford, W. T. Federer, A. E. Kehr, and L. C. Peterson, "Specific and general combining ability for yield in potatoes," American Potato Journal, vol. 39, no. 5, pp. 185-197, 1962.

[33] R. J. Killick and J. F. Malcolmson, "Inheritance in potatoes of field resistance to late blight [Phytophthora infestans (Mont.) de Bary]," Physiological Plant Pathology, vol. 3, no. 1, pp. 121-131, 1973.

[34] A. E. F. Neele, H. J. Nab, and K. M. Louwes, "Identification of superior parents in a potato breeding programme," Theoretical and Applied Genetics, vol. 82, no. 3, pp. 264-272, 1991.

[35] D. L. Savithramma, D. Rekha, and H. C. Sowmya, "Combining ability studies for growth and yield related traits in groundnut (Arachis hypogaea L.)," Electronic Journal of Plant Breeding, vol. 1, no. 4, pp. 1010-1015, 2010. 

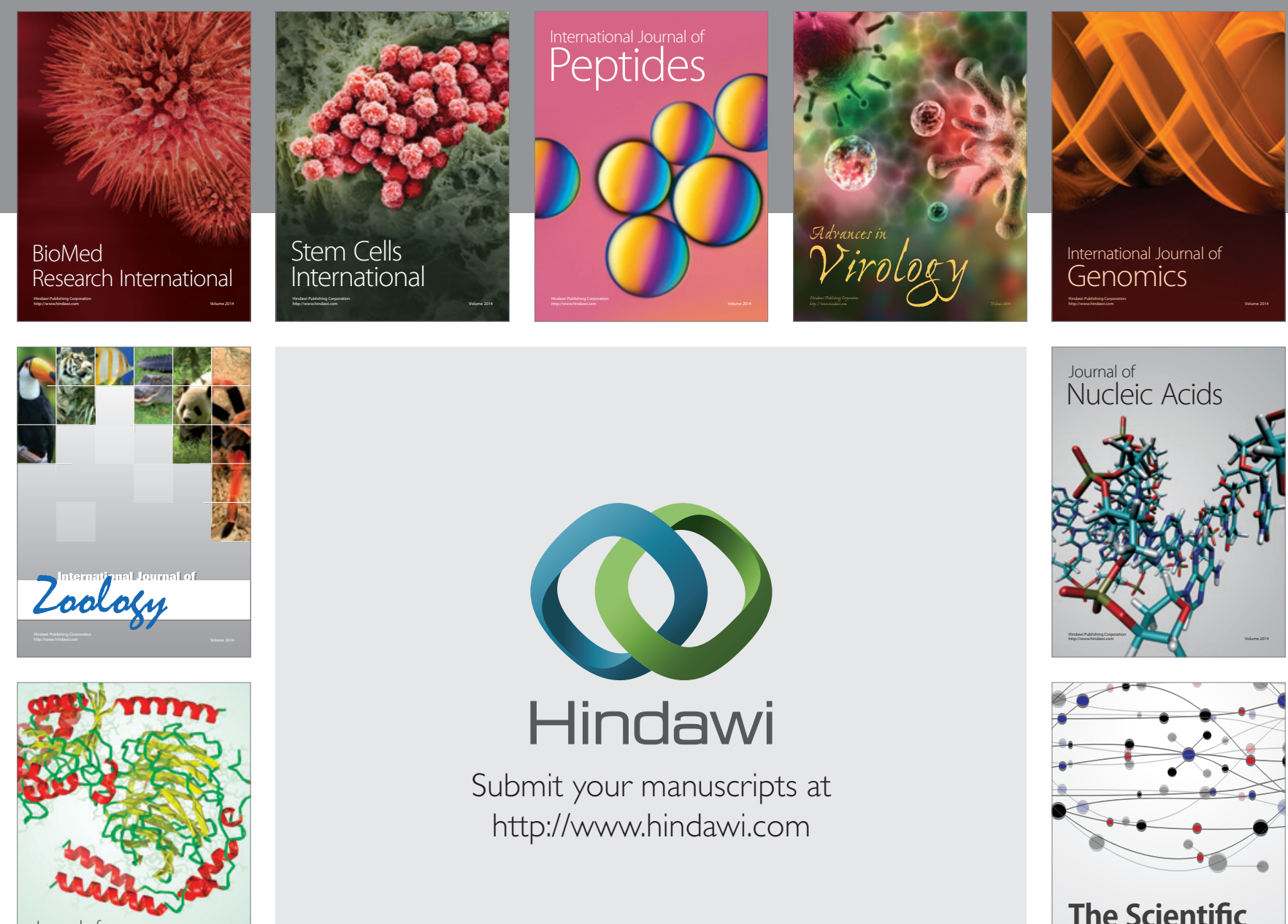

Submit your manuscripts at

http://www.hindawi.com

Journal of
Signal Transduction
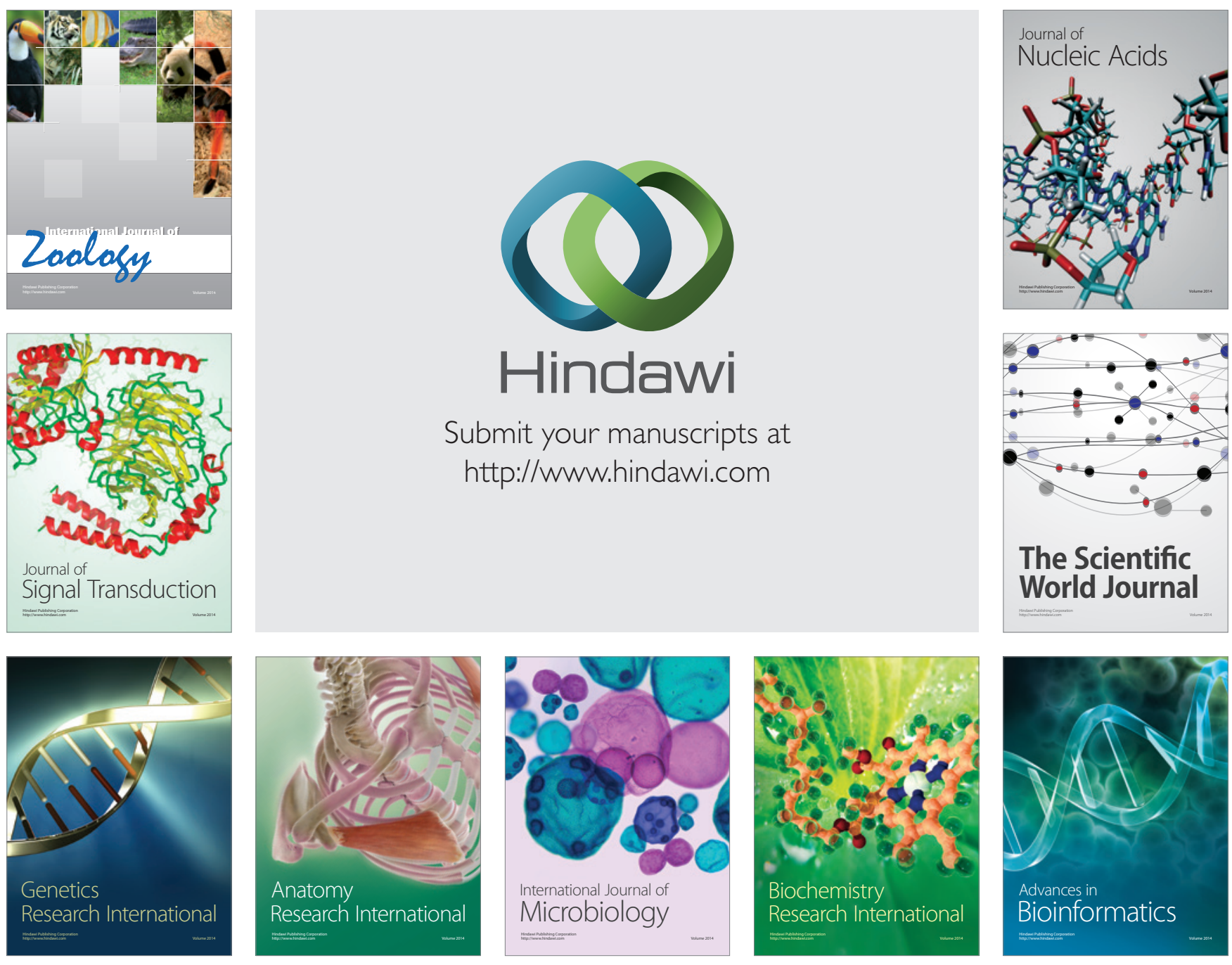

The Scientific World Journal
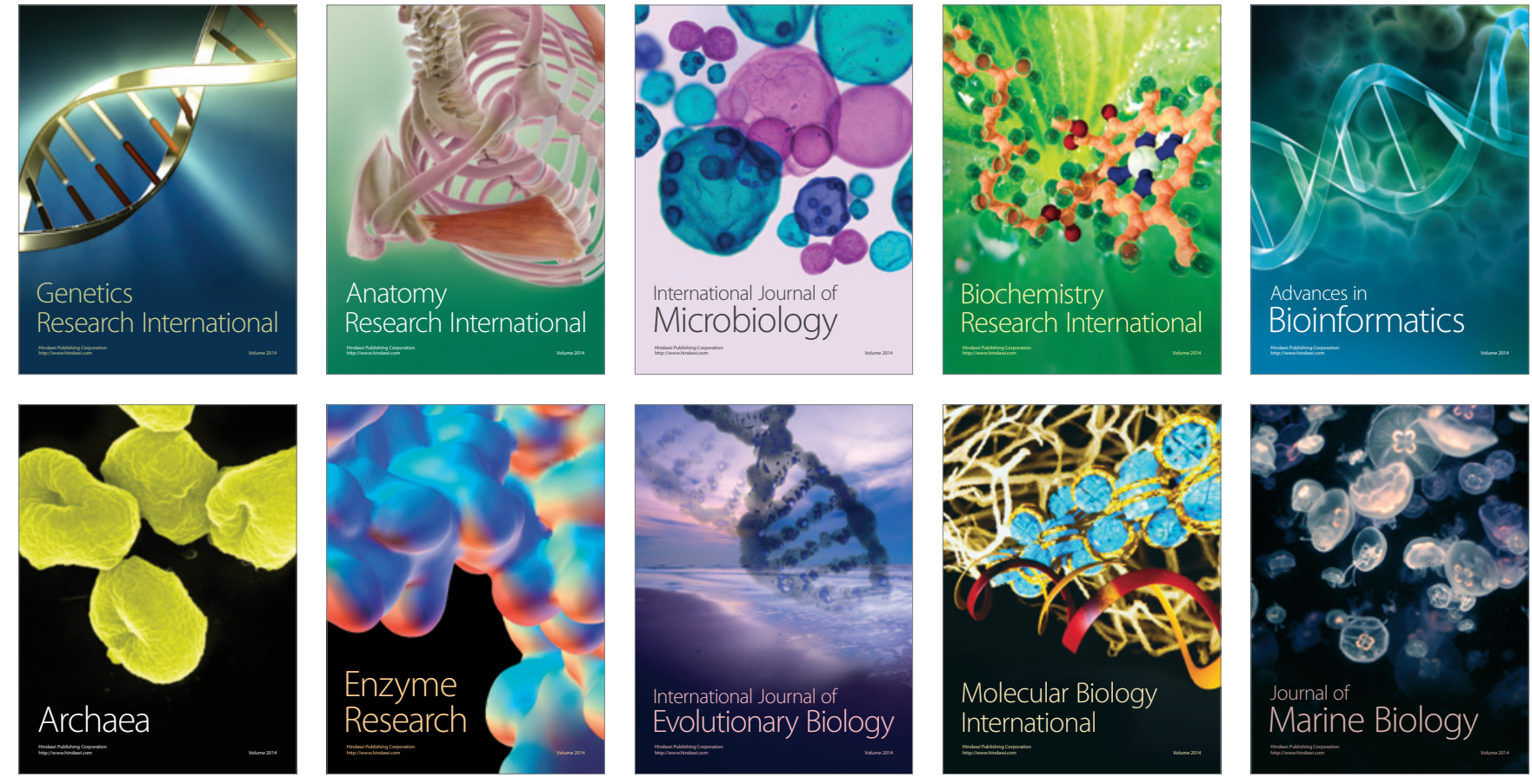